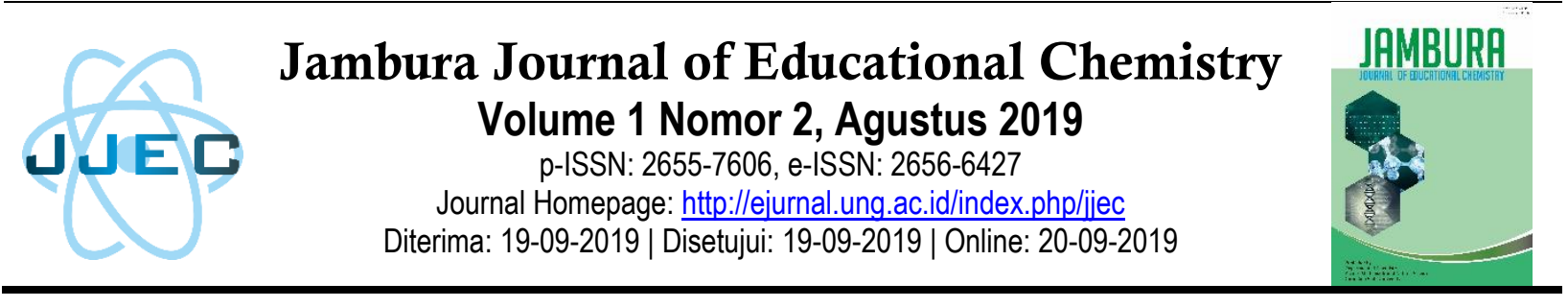

\title{
Peningkatan Aktivitas Belajar Siswa Melalui Pembelajaran Kimia Berbasis Budaya Lokal
}

\author{
Tamrin Taher ${ }^{1}$ \\ 1Jurusan Tadris Fakultas Tarbiyah dan Ilmu Keguruan IAIN Ternate \\ Jln Lumba-lumba Kel. Dufa-dufa Ternate 97727 \\ e-mail: tamrin@iain-ternate.ac.id
}

\begin{abstract}
Abstrak
Penelitian ini bertujuan untuk meningkatkan aktivitas belajar siswa pda mata pelajaran kimia menggunakan pendekatan berbasis budaya lokal. Penelitian dilaksanakan pada semester genap tahun ajaran 2017/2018 di Madrasah Aliyah Negeri 1 Kota Tidore Kepulauan untuk pokok bahasan Koloid. Subjek penelitian adalah siswa kelas XI MIPA 2 yang berjumlah 22 orang. Jenis penelitian ini adalah Action Research atau penelitian Tindakan Kelas yang dilaksanakan sebanyak dua siklus. Data dikumpulkan melalui lembar observasi dan dianalisis secara deskriptif. Hasil penelitian menunjukkan bahwa terjadi peningkatan aktivitas belajar siswa yang cukup signifikan dari pra-siklus, siklus I, dan siklus II. Rerata Aktivitas belajar siswa pada pra-siklus sebesar $21 \%$ dan mengalami peningkatan pada siklus I sebesar $72 \%$ serta $91 \%$ di siklus ke-II. Data tersebut manunjukkan bahwa aktivitas belajar siswa mengalami peningkatan yang cukup signifikan melalui pembelajaran berbasis budaya lokal.
\end{abstract}

Kata Kunci: aktivitas belajar, budaya lokal, koloid.

\section{PENDAHULUAN}

Ilmu kimia yang merupakan bagian dari sains masih menjadi momok bagi siswa di sekolah menengah atas. Beberapa topik dan konsep yang melibatkan aspek mikroskopis menjadi salah satu penyebab ilmu kimia dianggap sulit dipelajari karena bersifat abstrak. Disamping itu, mempelajari kimia membutuhkan kemampuan matematis untuk menyelesaikan beberapa persoalan yang bersifat stoikiometrik, belum lagi pembelajaran textual dan kurang mengaitkan konsep kimia dengan kehidupan sehari-hari menambah daftar penunjang ilmu kimia dianggap sukar.

Saat ini telah banyak tersedia alternatif metode model maupun media pembelajaran aktif dan interaktif, namun metode mengajar informatif (konvensional) masih menjadi idola bagi para guru termasuk dalam mengajarkan kimia kepada siswa. Walaupun metode ini terlihat efektif terutama dilihat dari segi alokasi waktu, namun kurang berdampak terhadap aktivitas belajar siswa. Aktivitas belajar membutuhkan fisik juga mental dalam meningkatkan kemampuan dan ketrampilan pada diri siswa (Oemar, 2005). Siswa yang aktif mampu menggali kemampuannya dari rasa ingin tahu sehingga interaksi yang terjadi akan menciptakan pengalaman dan keinginan untuk mengetahui sesuatu yang baru (Sardiman, 2011).

Abad 21 menuntut guru menempatkan siswa sabagai subjek pembelajaran (student centered learning) dan menciptakan suasana pembelajaran interaktif dimana siswa turut berperan dan bereksplorasi dalam kelas (Willingham, 2009). Menjadikan siswa sebagai objek yang mengharuskan mendengarkan seluruh penjelasan guru melalui metode ceramah mengakibatkan siswa tidak tertarik belajar kimia.

Salah satu topik kimia yang diajarkan pada kelas XI semester genap adalah tentang koloid. Materi yang bersifat non stoikiometrik ini sering 
diajarkan menggunakan metode ceramah. Akibatnya, aktivitas maupun hasil belajar siswa tidak optimal (Taher, 2018). Berdasarkan hasil observasi di Madrasah Aliyah Negeri 1 Tidore, ratarata presentase aktivitas siswa masih jauh dari harapan yakni hanya sebesar 21\%. Rendahnya aktivitas belajar tersebut dikarenakan penyampaian materi pembelajaran secara monoton oleh guru sehingga siswa merasa jenuh dan tidak termotivasi untuk terlibat dalam kegiatan pembelajaran.

Penelitian ini menggunakan pendekatan budaya lokal untuk meningkatkan aktivitas belajar siswa. budaya lokal (Local Wisdom) merupakan suatu kebiasaan baik yang dilakukan oleh masyarakat dalam kehidupannya. Kebiasaan baik tersebut tidak hanya berupa perbuatan, bisa dalam bentuk sastra, transisi religious, makanan khas dan seterusnya (Firza, 2016). Beragamanya budaya lokal disetiap daerah menjadi khasanah dan ciri khas tersendiri bagi darah tersebut termasuk Tidore. Budaya tersebut dapat dimanfaatkan dan dikaitkan dalam pembelajaran kimia agar siswa tertarik mengikuti pembelajaran. Sebagaimana hasil penelitian bahwa pembelajaran dengan pemanfaatan budaya lokal merangsang motivasi belajar dan rasa ingin tahu siswa untuk mengembangkan pengetahuan mereka tentang kimia dan budaya (Rahmawati \& Achmad, 2017)

\section{METODE PENELITIAN}

\section{Jenis Penelitian}

Jenis Penelitian ini adalah penelitian tindakan kelas (Classroom Action Research) yaitu suatu tindakan yang dilakukan untuk memperbaiki kualitas pembelajaran di kelas (Arikunto, 2008). Pendekatan yang digunakan adalah Culturally Responsive Teaching atau pendekatan berbasis budaya yang memanfaatkan pengetahuan budaya, pengalaman sebelumnya, dan gaya kinerja siswa yang beragam untuk dapat menimbulkan pengalaman belajar yang bermakna (Gay, 2000).

\section{Waktu dan Tempat Penelitian}

Penelitian ini dilaksanakan selama bulan April sampai dengan bulan Mei Tahun 2018 di Madrasah Aliyah Negeri 1 Tidore untuk pokok bahasan koloid

\section{Subjek Penelitian}

Subjek penelitian adalah kelas XI MIPA 2 MAN 1 Tidore yang berjumlah 22 orang yang terdiri dari 14 siswi putri dan 8 siswa putra.

\section{Prosedur Penelitian}

Desain penelitian menggunakan model Kemmis dan Taggart yang terdiri dari perencanaan (planning), pelaksanaan tindakan (action), pengamatan (observing), dan refleksi (reflection) disetiap siklusnya (Kemmis, 1992)

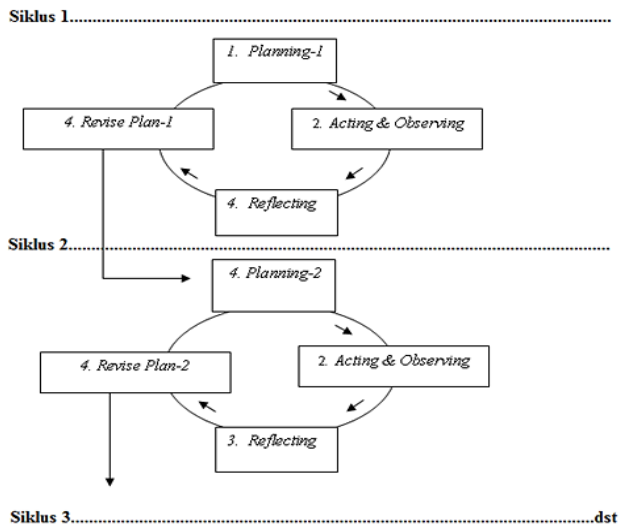

Gambar 1. Alur PTK Menurut Kemmis dan Taggart

\section{Teknik Pengumpulan Data}

Teknik pengumpulan data dilakukan melalui observasi dan dokumentasi oleh observer berdasarkan panduan observasi yang telah disiapkan. Observasi dilakukan terhadap aktivitas siswa selama proses pembelajaran.

\section{Teknik Analisis Data}

Data hasil observasi diuraikan dan dianalisis secara deskriptif. Tindakan dikatakan berhasil jika seluruh atau sebagian besar siswa $(\geq 75 \%)$ memiliki aktvitas baik selama pembelajaran (Mulyasa, 2006)

\section{HASIL DAN PEMBAHASAN}

Penelitian dilaksanakan sebanyak dua siklus, Setiap siklus dilakukan sebanyak dua kali pertemuan. Sebelum dilakukan tindakan, terlebih dahulu dilaksanakan pra-tindakan.

\section{Pra-Tindakan}

Pra-tindakan dilakukan untuk melihat aktivitas siswa menggunakan metode pembelajaran yang sering digunakan guru (metode ceramah). Hasil observasi Pra-Tindakan menunjukkan bahwa terdapat 10 siswa (45\%) yang terlibat dalam 
membuat catatan dan tugas yang diberikan guru; sebanyak 7 siswa (32\%) antusias dalam memperhatikan penjelasan guru/teman; 6 siswa (27\%) aktif dalam mebaca materi pelajaran maupun bertanya; hanya 3 siswa (14\%) yang menanggapi pertanyaan; serta tidak ada siswa $(0 \%)$ yang terlibat dalam aktivitas-aktivitas kelompok seperti berdiskusi, dan memperhatikan anggota kelompoknya.

Hasil observasi pra-tindakan memperlihatkan bahwa, rata-rata presentase aktivitas siswa sangat rendah. Rendahnya aktivitas belajar siswa dikarenakan metode pembelajaran yang monoton dan kurang memancing siswa untuk terlibat selama pembelajaran. Metode tersebut lebih menekankan untuk membangun kemampuan siswa secara individual tanpa memeprtimbangkan aktivitas siswa secara berkelompok.

\section{Siklus I}

Tindakan siklus pertama dilakukan dengan pendekatan berbasis budaya lokal menggunakan Model Cooperatif Learning Tipe Student Team Achievmant Division (STAD). Mula-mula siswa dibagi ke dalam kelompok kecil yang beranggotakan 5 sampai 6 orang. Siswa kemudian diberi artikel yang berkaitan dengan budaya lokal. Artikel yang diberikan mamiliki tema "Jel Kaya Nutrisi". Artikel tersebut berisikan deskripsi mengenai makanan khas masyarakat Tidore dan sekitarnya yakni papeda atau popeda yang terbuat dari pohon sagu atau singkong.

Masing-masing kelompok diminta berdiskusi mengenai Artikel tersebut terutama komponen atau bahan pembuatan popeda yang merupakan bagian dari contoh system koloid. Selanjutnya mereka diminta berdiskusi memecahkan masalah/pertanyaan yang terdapat dalam artikel tersebut dan mempresentasikannya. Hasil observasi aktivitas pembelajaran siklus I diperoleh; sebesar 10 siswa (45\%) terlibat dalam pembuatan catatan; 12 siswa (55\%) aktif membaca materi; 13 siswa (59\%) telah berani mengajukan pertanyaan; 15 siswa (68\%) menanggapi pendapat orang lain; 16 siswa (72\%) mengemukakan pendapat dalam kelompok; 18 siswa (82\%) memiliki kepedulian terhadap kelompok; 19 siswa $(86 \%)$ antusias terhadap penjelasan guru/teman serta berdiskusi dalam kelompok dan sebanyak 20 siswa (91\%) mengerjakan tugas yang diberikan guru.

Presentase hasil belajar pada siklus pertama terlihat mengalami peningkatan dibanding pratindakan terutama dalam aktivitas bekerja sama. Hal ini dikarenakan siswa dilibatkan secara berkelompok untuk menemukan dan mencari solusi atas masalah yang disajikan dalam artikel. Selain itu, penyajian masalah dalam artikel yang berkaitan dengan budaya setempat juga berefek terhadap aktivitas bertanya dan mengemukakan pendapat, ini terjadi karena siswa telah memiliki pengetahuan awal tentang topik yang dibahas karena relavan dengan apa yang dialaminya.

Meskipun demikian, terdapat beberapa item seperti membaca materi dan mengajukan pertanyaan maupun membuat catatan belum mengalami peningkatan secara signifikan. Disamping itu, rata-rata presentase aktivitas belajar siswa belum mencapai $75 \%$ atau lebih sehingga perlu diadakan siklus berikutnya.

\section{Siklus II}

Tindakan siklus kedua dilakukan dengan mengkolaborasikan pendekatan berbasis budaya lokal dan Project Base Learning (PjBL). Mula-mula siswa dibagi ke dalam kelompok kecil yang beranggotakan 5 sampai 6 orang. Siswa kemudian diberi artikel yang berkaitan dengan budaya lokal. Kali ini Artikel yang diberikan mamiliki tema "Sang Jawara Lebaran". Artikel tersebut berisikan deskripsi mengenai kue khas lebaran masyarakat Tidore (kue bilolo) yang selalu disajikan terutama saat lebaran idul Fitri maupun Idul Adha.

Bersama kelompoknya siswa berdiskusi tentang kue khas tersebut dan menjawab pertanyaan yang disajikan dalam artikel. Selanjutnya siswa diminta membuat project secara berkelompok tentang budaya lokal yang berkaitan dengan konsep koloid. Masing-masing kelompok selanjutnya diminta mempresentasekan hasil kerja project kelompoknya. 

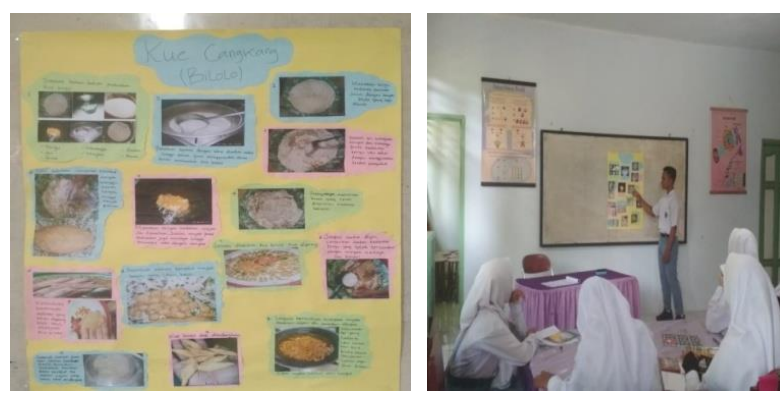

Gambar 2. Presentase Hasil Project Siswa

Hasil observasi pada siklus kedua menunjukkan bahwa aktivitas siswa selama pembelajaran menggunakan pendekatan berbasis budaya lokal mengalami peningkatan yang signifikan. Sebanyak 18 siswa (82\%) telah berani mengemukakan dan menanggapi pendapat dari guru maupun temannya; sebanyak 19 siswa (86\%) aktif terlibat dalam membaca materi dan membuat catatan; akitvitas siswa dalam mengajukan pertanyaan, memperhatikan penjelasan guru/siswa, melakukan diskusi kelompok serta peduli terhadap sesama anggota kelompok menjacapai $95 \%$ atau sebanyak 21 siswa; sementara seluruh siswa (100\%) siswa terlibat adalam mengerjakan tugas/Project yang diberikan guru.

Adanya peningkatan aktivitas belajar siswa untuk materi koloid tersebut tidak terlepas dari motivasi dan antusias belajar mereka menggunakan pendekatan berbasis budaya daerah dimana mereka tempati. Ringkasan observasi disajikan pada tabel berikut.

Tabel 1. Presentase Aktivitas Belajar Siswa Pra-Tindakan, Siklus I dan Siklus II

\begin{tabular}{clccc}
\hline \multirow{2}{*}{ No } & \multicolumn{1}{c}{ Indikator } & \multicolumn{3}{c}{ Presentase (\%) } \\
\cline { 3 - 5 } & & $\begin{array}{c}\text { Pra- } \\
\text { Tindakan }\end{array}$ & Siklus I & Sikus II \\
\hline 1 & Membaca Materi & 27 & 55 & 86 \\
2 & Mengajukan pertanyaan kepada guru atau teman & 27 & 59 & 95 \\
3 & Mengemukakan pendapat dalam diskusi kelompok & 0 & 72 & 82 \\
4 & Menanggapi pendapat orang lain & 14 & 68 & 82 \\
5 & Memperhatikan penjelasan guru/teman & 32 & 86 & 95 \\
6 & Membuat Catatan & 45 & 45 & 86 \\
7 & Melakukan diskusi dalam kelompok & 0 & 86 & 95 \\
8 & Mengerjakan tugas yang diberikan guru & 45 & 91 & 100 \\
9 & Kepedulian terhadap sesama anggota & 0 & 82 & 95 \\
\hline & Rata-Rata & $\mathbf{2 1}$ & $\mathbf{7 2}$ & $\mathbf{9 1}$ \\
\hline
\end{tabular}

Tabel di atas memperlihatkan Rerata aktivitas belajar siswa pada Pra-tindakan hanya sebesar $21 \%$, meningkat pada siklus pertama menjadi $72 \%$ dan naik sebesar $18 \%$ menjadi $91 \%$ pada siklus ke II. Dengan demikian maka tindakan. Dikarenakan aktivits belajar pada siklus kedua telah mencapai $91 \%$ atau lebih dari $75 \%$ siswa telah terlibat secara aktif selama kegaiatn belajar berlangsung, maka tidak dilanjutkan ke siklus berikutnya. Rata-rata peningkatan aktivitas belajar siswa di setiap siklus dapat dilihat pada diagram berikut.

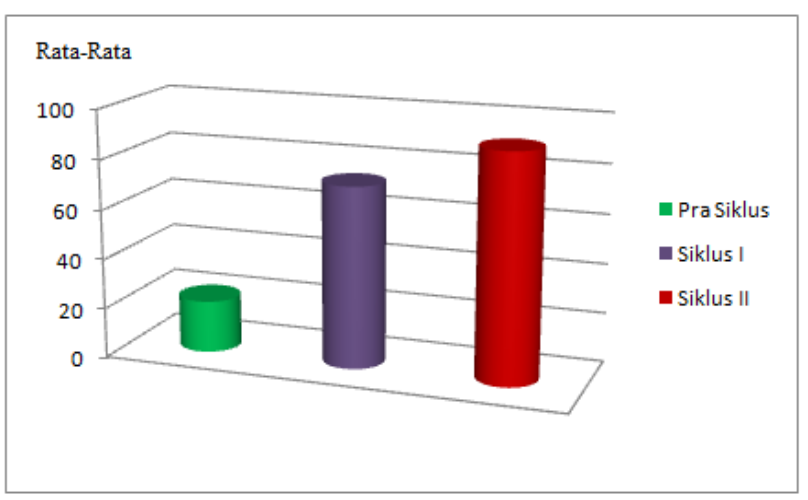

Gambar 3. Rata-rata peningkatan aktivitas belajar siswa Pra-tindakan, Siklus I dan Siklus II. 
Adanya peningkatan aktivitas belajar tidak terlepas dari penerapan metode berbasis budaya lokal dengan menginternalisasi budaya setempat ke dalam pembelajaran agar topik yang disampaikan dapat terjangkau oleh nalar siswa karena berkaitan dengan pengalaman nyata atau peristiwa yang telah meraka alami bahkan lakukan.

\section{SIMPULAN}

Berdasarkan hasil penelitian yang telah dilakukan, maka dapat diambil kesimpulan bahwa aktivitas belajar siswa MAN 1 Kota Tidore Kepulauan pada pembelajaran kimia pokok bahasan koloid mengalami peningkatan dengan pendekatan berbasis budaya lokal. Pendekatan ini juga dapat dikolaborasikan dengan model lain seperti STAD, $\mathrm{PjBL}$ atau model kooperatif lainnya.

\section{UCAPAN TERIMA KASIH}

Ucapan terima kasih disampaikan kepada Dra. Hj. Sumarni Umar, M.Pd.I selaku Kepala Madrasah Aliyah Negeri 1 Kota Tidore Kepulauan yang telah memberikan izin untuk melakukan penelitian di MAN 1 Tidore.

Terima kasih juga disampaikan kepada guru bidang study kimia kelas XI Bapak Basri M. Nur, S.Pd yang telah membantu dan mendampingi selama melakukan penelitian di MAN 1 Tidore.

\section{DAFTAR PUSTAKA}

Sardiman, A. M. (2011). Interaksi dan Motivasi Belajar Mengajar. Jakarta: Rajawali Press.
Arikunto, S., Suhardjono, dan Supardi. (2008). Penelitian Tindakan Kelas. Jakarta: Bumi Aksara.

Firza. (2016). Local Wisdom Sebagai Dasar dalam Pembentukan Karakter. In Seminar Nasional Reforming Pedagogy. Yogyakarta: Fakultas Keguruan dan Ilmu Pendidikan Universitas Sanata Dharma.

Gay, G. (2000). Culturally Responsive Teaching: Theory, Practice, and Research. New York: Teachers College Press.

Kemmis, S \& Taggart, Mc. R. (1992). The action Research Planner. Australia: Deakin University.

Mulyasa. (2006). Menjadi Guru Profesional (Menciptakan Pembelajaran Kreatif dan Menyenangkan). Bandung: Remaja Rosdakarya

Oemar, H. (2005). Metode Belajar dan Kesulitankesulitan Belajar. Bandung: Tarsito

Rahmawati, Y \& Achmad, Ridwan. (2017) Empowering students' chemistry learning: the integration of ethnochemistry in culturally responsive teaching. Chemistry: Bulgarian Journal of Science Education, Volume 26 (6), 1-20.

Taher, T. (2018). Pengaruh Model Problem Based Learning dan Tipe Kepribadian Terhadap Kemampuan Berpikir Kritis Siswa pada Materi Koloid. Journal Riset Pendidikan Kimia Vol. 8(1), 8-34

Willingham \& Rotherham, A. J. (2009). 21 $1^{s t}$ Century Skills: the Challenges Ahead Educational Leadership Volume 67 Number 1 . 